\title{
Organic and conventional solanaceous vegetables: Comparison of phenolic constituents, antioxidant and antibacterial potentials
}

\author{
S. Basay ${ }^{1}$, A. Cimen ${ }^{2}$, Y. Baba ${ }^{2}$, A.B. Yildirim ${ }^{3}$ and A.U. Turker ${ }^{2 *}$ (1) \\ ${ }^{1}$ Department of Horticulture, Faculty of Agriculture, Bursa Uludağ University, Bursa, Turkey \\ 2 Department of Biology, Faculty of Arts and Sciences, Bolu Abant Izzet Baysal University, Bolu, Turkey \\ ${ }^{3}$ Department of Field Crops, Faculty of Agriculture, Bolu Abant Izzet Baysal University, Bolu, Turkey
}

\section{ORIGINAL RESEARCH PAPER}

Received: April 2, 2021 • Accepted: June 3, 2021

Published online: July 8, 2021

(C) 2021 The Author(s)

\begin{abstract}
Interest in organic growing systems that means no harm to the environment, mankind, and the world's natural ecosystem is increasing. This study evaluated the impact of organic versus conventional cultivation method on eggplants (Topan-374 and Pala-49), tomatoes (Rio Grande and Pink), and bell pepper (Kandil dolma) considering individual phenols, total phenol-flavonoid content, antioxidant capacity, and antibacterial potential. Peel and pulp of eggplants were evaluated separately. Organic cultivation enhanced trans-ferulic acid in the peels of both eggplant cultivars and the pulp of Pala- 49 . Organic Pala- 49 had also higher amounts of cyanidin and caffeic acid in the peel, and only caffeic acid in the pulp. Chlorogenic acid was found in higher quantities in organic Rio Grande tomato and bell pepper. All organically grown vegetables in our study had significantly higher total phenol and flavonoid contents than conventional ones except Pink tomato. Organic farming significantly enhanced the antioxidant capacity of both eggplant cultivars. Only organic peel of Pala-49 eggplant cultivar had antibacterial activity against Staphylococcus epidermidis. Organic cultivation has an advantage in terms of antioxidant potential and phenolic constituents, and it enhanced the nutraceutical potential of both cultivars of eggplant, Rio Grande tomato, and bell pepper.
\end{abstract}

\footnotetext{
*Corresponding author. E-mail: turker_a@ibu.edu.tr
} 


\section{KEYWORDS}

antibacterial, antioxidant, bell pepper, eggplant, phenol, tomato

\section{INTRODUCTION}

Organic agriculture is a system that preserves the balance in nature, ensures continuity in soil fertility, preserves the continuity of living things in nature by controlling diseases and pests, and obtains optimum efficiency with the use of natural resources and energy (Yüzbaşığlu, 2018).

Phenolic compounds are secondary metabolites produced by plants during growth and reproduction, as well as in response to a number of biotic and abiotic stresses. Phenols having antioxidant properties interfere with the production of free radicals and also play a key role to inactivate them. Phenolic compounds are involved in prevention of several diseases related to oxidative and nitrosative stresses, such as cancer, diabetes mellitus, cardiovascular diseases, hypertension, atherosclerosis, and neurological disorders (Faller and Fialho, 2010; Caleja et al., 2017; Niño-Medina et al., 2017). Organic food is expected to have a higher antioxidant potential as organic cultivation systems encourage the production of secondary compounds, like polyphenols (Faller and Fialho, 2010). Solanaceous fruits play an important role in human nutrition, and this family's most popular fruit crops are eggplant, tomato, and chili/ pepper (Yamaguchi, 1983). These vegetables have attracted a lot of attention as functional food in recent years because of their high phenolic content and antioxidant activity (Simonne, 2011; Niño-Medina et al., 2017). The present study concerned the comparison of individual phenols, total phenol and flavonoid contents, antioxidant capacity, and antibacterial activity of some solanaceous vegetables growing with organic and conventional cultivation system.

\section{MATERIALS AND METHODS}

\subsection{Cultivation of vegetables}

This study was carried out in "Organically Certified" and "Conventional" fields in Application and Production Farm, Faculty of Agriculture, Bursa Uludağ University. The experiment was carried out in two growing seasons of 2018 and 2019. Organic Agriculture Regulation was followed completely in determining the distance between organic and conventional parcels and organic cultivation (Official Gazette, 2010). The climate, weather, and soil conditions were very similar on both cultivation systems. Two eggplant cultivars (Pala-49 and Topan374), two tomato cultivars (Rio Grande and Pink tomato), and one pepper cultivar (Kandil Dolma) were used for both cultivation (Table 1). Farm manure sherbet was used in organic farming, and commercial fertilisers (NPK fertiliser; 15:15:15-Plantİstanbul ${ }^{\circledR}$ and ammonium nitrate; $26 \%$ ) were applied in conventional cultivation. Irrigation and fertilisation processes were applied in parallel in both cultivations. All vegetables were harvested at commercial maturity. 


\subsection{Extract preparation}

Each vegetable obtained from two sources (organically and conventionally cultivated) for two years were freeze-dried, powdered, extracted with methanol at $40{ }^{\circ} \mathrm{C}$ for $24 \mathrm{~h}$, and then vacuum evaporated. Extraction yields of each extract are presented in Table 1.

\subsection{HPLC-DAD analysis}

Six different phenolic substances (chlorogenic acid, cyanidin, caffeic acid, trans-ferulic acid, gallic acid, and quercetin) (Sigma ${ }^{\circledR}$ ) were quantitatively analysed in methanol extract of vegetables using HPLC-DAD as described by Turker et al. (2021) with slight modifications (gradient elution with acetonitrile and $0.1 \%$ orthophosphoric acid). The chromatogram of the used standards is presented in Fig. 1.

\subsection{Free radical scavenging activity and total phenol-flavonoid content}

Free radical scavenging activity of the vegetables was evaluated by DPPH (1,1-diphenyl-2-picrylhydrazyl) assay that is based on DPPH disappearance at $517 \mathrm{~nm}$ in samples according to Blois's (1958) method with some modifications. Concisely, $0.1 \mathrm{~mL}$ of various concentrations of extracts or quercetin (antioxidant standard) were prepared in methanol and mixed with $1.4 \mathrm{~mL}$ of DPPH solution, which were then kept in the dark for $30 \mathrm{~min}$ before the absorbance of the samples was measured against the blank (methanol) with a UV-VIS Spectrophotometer (Hitachi $\mathrm{U}-1900^{\circledR}$ ). Folin-Ciocalteu and aluminium chloride colorimetric methods were used as described by Turker et al. (2021).

\subsection{Antibacterial assay}

Antibacterial activity of vegetable extracts was assessed by disc diffusion assay as described by Turker et al. (2021). Three Gram-positive bacteria (Staphylococcus epidermidis, Staphylococcus

Table 1. Cultivar, designation, and extraction yields of tested vegetables

\begin{tabular}{|c|c|c|c|c|c|}
\hline Vegetables & Cultivar & Fruit parts & Cultivation & Designation & Yield $(\%)^{\mathrm{a}}$ \\
\hline \multirow{8}{*}{$\begin{array}{l}\text { Eggplant } \\
\text { (Solanum melongena L.) }\end{array}$} & \multirow[t]{4}{*}{ Topan-374 } & \multirow[t]{2}{*}{ Pulp } & C & $\mathrm{CTE}_{\text {pulp }}$ & 14.5 \\
\hline & & & $\mathrm{O}$ & OTE $_{\text {pulp }}$ & 21 \\
\hline & & \multirow[t]{2}{*}{ Peel } & $\mathrm{C}$ & $\mathrm{CTE}_{\text {peel }}$ & 9.9 \\
\hline & & & $\mathrm{O}$ & $\mathrm{OTE}_{\text {peel }}$ & 13.3 \\
\hline & \multirow[t]{4}{*}{ Pala-49 } & \multirow[t]{2}{*}{ Pulp } & $\mathrm{C}$ & $\mathrm{CPE}_{\text {pulp }}$ & 17.5 \\
\hline & & & $\mathrm{O}$ & $\mathrm{OPE}_{\text {pulp }}$ & 19.1 \\
\hline & & \multirow[t]{2}{*}{ Peel } & $\mathrm{C}$ & $\mathrm{CPE}_{\text {peel }}$ & 8.1 \\
\hline & & & $\mathrm{O}$ & $O P E_{\text {peel }}$ & 9.7 \\
\hline \multirow{4}{*}{$\begin{array}{l}\text { Tomato } \\
\qquad \text { (Lycopersicon esculentum L.) }\end{array}$} & \multirow[t]{2}{*}{ Rio grande } & \multirow[t]{2}{*}{ Whole } & $\mathrm{C}$ & CRT & 25.1 \\
\hline & & & $\mathrm{O}$ & ORT & 35.6 \\
\hline & \multirow[t]{2}{*}{ Pink } & \multirow[t]{2}{*}{ Whole } & $\mathrm{C}$ & $\mathrm{CPT}$ & 21.6 \\
\hline & & & $\mathrm{O}$ & OPT & 37.3 \\
\hline \multirow{2}{*}{$\begin{array}{l}\text { Bell pepper } \\
\quad \text { (Capsicum annuum L.) }\end{array}$} & \multirow[t]{2}{*}{ Kandil Dolma } & \multirow[t]{2}{*}{ Whole } & $\mathrm{C}$ & CKDP & 20.5 \\
\hline & & & $\mathrm{O}$ & OKDP & 18.1 \\
\hline
\end{tabular}

C: Conventional, O: Organic; ${ }^{\mathrm{a} E x t r a c t i o n}$ yield $(\%)=$ weight of extract $(\mathrm{g}) / 20 \mathrm{~g}$ of fruit sample $\times 100$. 


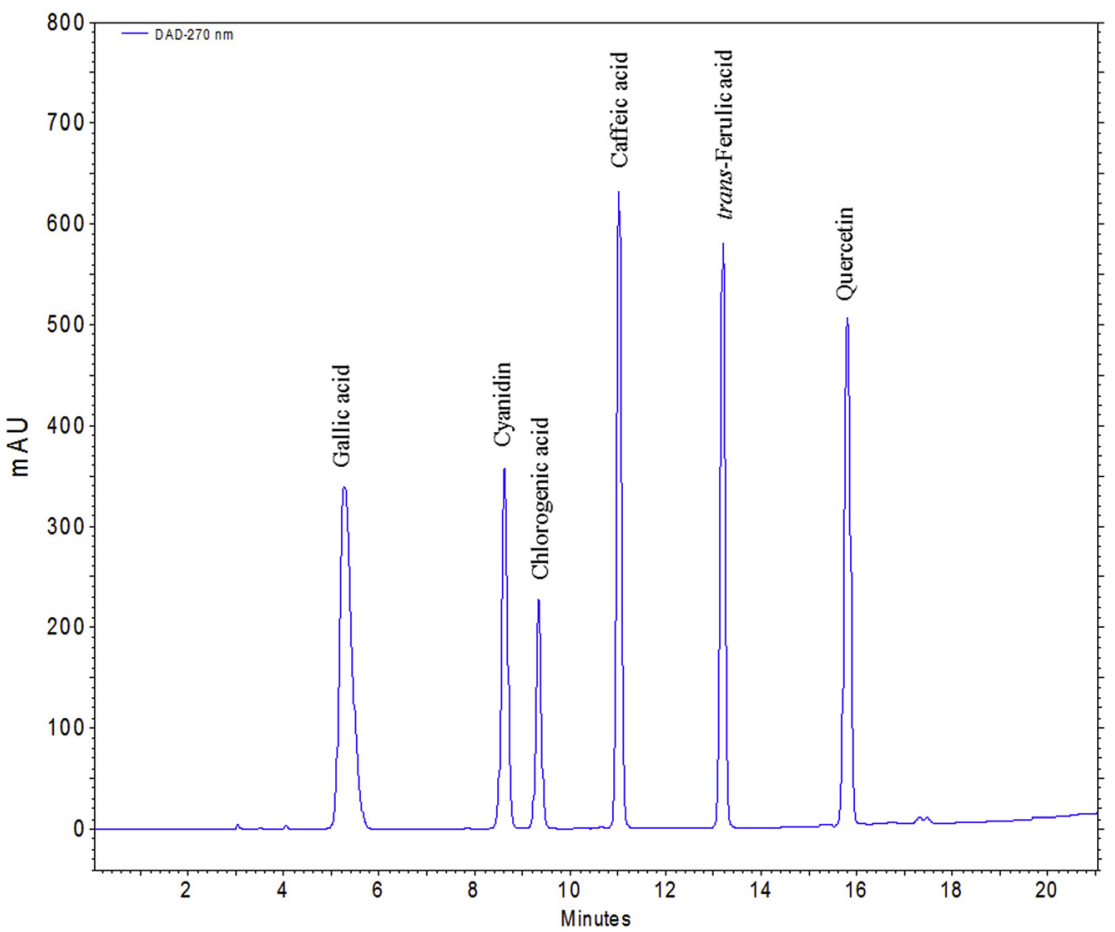

Fig. 1. Chromatogram of the standards. Retention times: 1 . Gallic acid $-4.99 \mathrm{~min}, 2$. Cyanidin $-8.89 \mathrm{~min}$, 3. Chlorogenic acid - $9.52 \mathrm{~min}$, 4. Caffeic acid $-11.18 \mathrm{~min}, 5$. $t$-Ferulic acid $-13.36 \mathrm{~min}$, 6. Quercetin $15.98 \mathrm{~min}$

aureus, and Streptococcus pyogenes) and seven Gram-negative bacteria (Klebsiella pneumoniae, Escherichia coli, Pseudomonas aeruginosa, Salmonella typhimurium, Serratia marcescens, Proteus vulgaris, and Enterobacter cloacae) were employed.

\subsection{Statistical analysis}

Data analysis was performed using analysis of variance (ANOVA) and Duncan's multiple range tests using SPSS vers. 26 (SPSS Inc, Chicago, IL, USA). All data in the tables are presented as a mean value of 2 years \pm standard error (SE). Pearson correlation analysis was performed for the determination of relationship.

\section{RESULTS AND DISCUSSION}

When the vegetables studied were evaluated together, peels of both eggplant cultivars obtained from both organic and conventional systems had the most individual phenolic substances (Fig. 2). Organic peel of Pala-49 cultivar had the highest amount of $t$-ferulic acid, cyanidin, and caffeic acid. Gallic acid and quercetin were not detected in any tested vegetables (Table 2). Total phenolic contents of all studied vegetables were improved with organic cultivation. The highest 


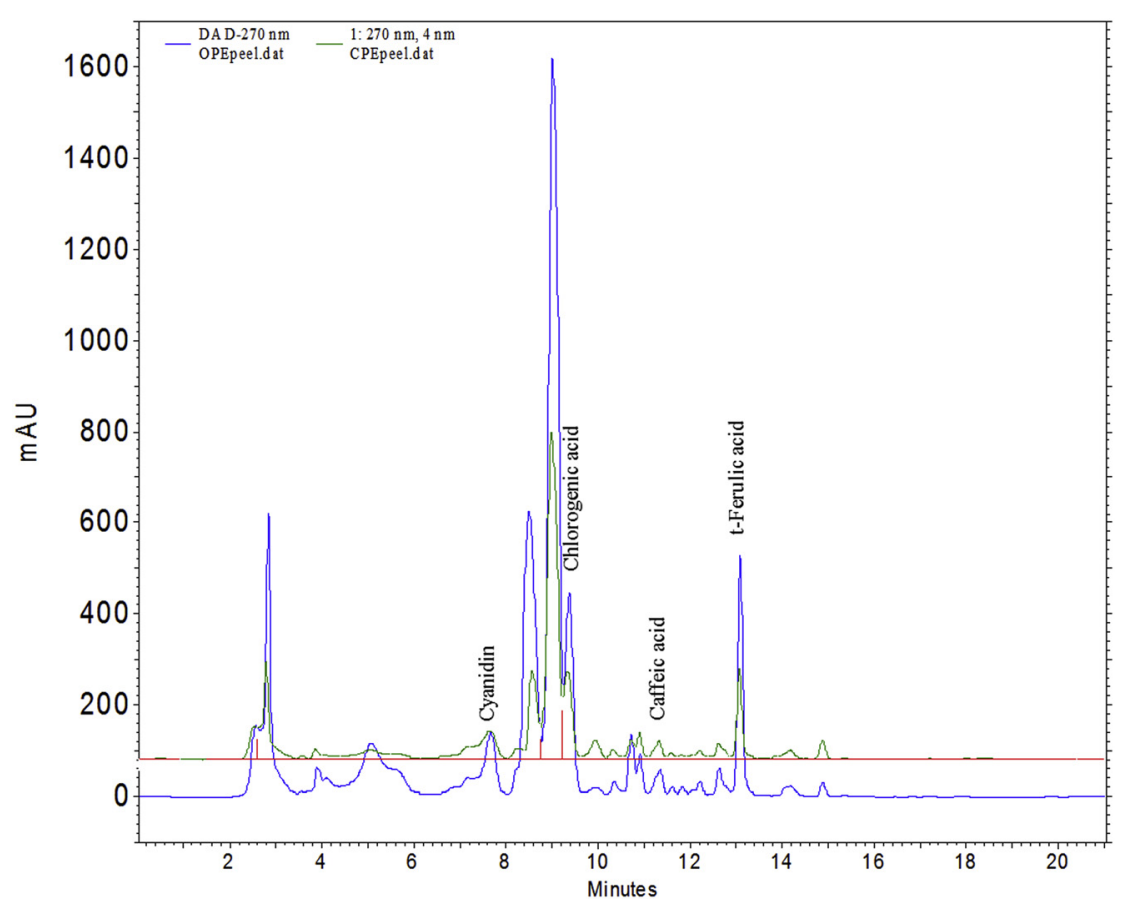

Fig. 2. Chromatograms of organic and conventional peels of Pala-49 eggplant cultivar $\left(\mathrm{OPE}_{\text {peel }}\right.$ and $\mathrm{CPE}_{\text {peel }}$, respectively)

total phenolic content was observed with organically grown Rio Grande tomato and bell pepper (134.13 and $89.03 \mathrm{mg} \mathrm{GAE/g,} \mathrm{respectively).} \mathrm{Parallel} \mathrm{to} \mathrm{the} \mathrm{results} \mathrm{of} \mathrm{total} \mathrm{phenolics,} \mathrm{all} \mathrm{organ-}$ ically grown vegetables demonstrated higher total flavonoid content than conventional ones except Pink tomato cultivar. Among the studied vegetables, the highest total flavonoid content was obtained with organically grown peels of Pala-49 and Topan-374 cultivars of eggplant (125.84 and $72.8784 \mathrm{mg} \mathrm{QE/g,} \mathrm{respectively)} \mathrm{(Table} \mathrm{3).} \mathrm{Only} \mathrm{organically} \mathrm{grown} \mathrm{peel} \mathrm{of} \mathrm{Pala-49}$ cultivar showed strong antibacterial activity against S. epidermidis (Table 4).

Peel and pulp of eggplants were evaluated separately for each cultivar. Peels of both eggplant cultivars had more phenolic substances than pulps. Organic cultivation affected Pala- 49 cultivar more positively than Topan-374 in terms of individual phenolic substances. Organically raised Pala-49 cultivar had higher levels of $t$-ferulic acid, cyanidin, and caffeic acid in the peels, and higher levels of $t$-ferulic acid and caffeic acid in the pulp. $t$-Ferulic acid was enhanced 1.94 times in the peel and 1.64 times in the pulp of Pala- 49 cultivar with organic farming. It was also elevated 2.83 times in the peel of Topan-374 cultivar. Cyanidin and caffeic acid showed 1.38 and 1.44 folds increase in the peel and 5.3 folds in the pulp of organically raised Pala- 49 cultivar. Chlorogenic acid content was not enhanced by the organic cultivation in eggplant, and it was found in higher amounts in conventional peels of both cultivars and in the pulp of Pala- 49 cultivar. Cyanidin and caffeic acid were also detected more in the peel of conventionally grown Topan-374 cultivar (Table 2). Remarkable enhancement in antioxidant capacity was observed in the peels and pulps of both organically grown eggplant cultivars. Especially, organic cultivation improved antioxidant 
Table 2. Quantitative analyses of phenolic compounds with HPLC-DAD in methanol extract of vegetables. Different letters in each column show significant differences $(P<0.05)$

\begin{tabular}{|c|c|c|c|c|c|c|}
\hline \multirow{2}{*}{$\begin{array}{l}\text { Vegetable } \\
\text { extracts } \\
\text { Designation }\end{array}$} & \multicolumn{4}{|c|}{ Phenolic compounds ( $\mathrm{mg} \mathrm{g}^{-1}$ dry extract) } & \multirow[b]{2}{*}{$\begin{array}{l}\text { Gallic } \\
\text { acid }\end{array}$} & \multirow[b]{2}{*}{ Quercetir } \\
\hline & $\begin{array}{l}\text { Chlorogenic } \\
\text { acid }\end{array}$ & Cyanidin & Caffeic acid & $t$-Ferulic acid & & \\
\hline $\mathrm{CTE}_{\text {pulp }}$ & $1.40 \pm 0.09^{\mathrm{d}}$ & - & $0.07 \pm 0.04^{\mathrm{d}}$ & $0.47 \pm 0.01^{\mathrm{ef}}$ & - & - \\
\hline OTE $_{\text {pulp }}$ & $1.45 \pm 0.00^{\mathrm{d}}$ & - & $0.05 \pm 0.03^{\mathrm{d}}$ & $0.32 \pm 0.04^{\mathrm{ef}}$ & - & - \\
\hline $\mathrm{CTE}_{\text {peel }}$ & $7.74 \pm 0.20^{\mathrm{a}}$ & $1.97 \pm 0.04^{\mathrm{b}}$ & $0.28 \pm 0.02^{\mathrm{b}}$ & $0.66 \pm 0.40^{\mathrm{de}}$ & - & - \\
\hline $\mathrm{OTE}_{\text {peel }}$ & $5.06 \pm 0.01^{\mathrm{b}}$ & $1.07 \pm 0.00^{\mathrm{d}}$ & $0.14 \pm 0.00^{\mathrm{c}}$ & $1.87 \pm 0.01^{\mathrm{c}}$ & - & - \\
\hline $\mathrm{CPE}_{\text {pulp }}$ & $1.34 \pm 0.07^{\mathrm{d}}$ & - & $0.03 \pm 0.00^{\mathrm{d}}$ & $0.54 \pm 0.00 \mathrm{def}$ & - & - \\
\hline $\mathrm{OPE}_{\text {pulp }}$ & $0.65 \pm 0.02^{\mathrm{efg}}$ & - & $0.16 \pm 0.00^{c}$ & $1.05 \pm 0.00^{\mathrm{d}}$ & - & - \\
\hline $\mathrm{CPE}_{\text {peel }}$ & $7.64 \pm 0.12^{\mathrm{a}}$ & $1.56 \pm 0.03^{\mathrm{c}}$ & $0.27 \pm 0.00^{\mathrm{b}}$ & $2.77 \pm 0.00^{\mathrm{b}}$ & - & - \\
\hline $\mathrm{OPE}_{\text {peel }}$ & $4.10 \pm 0.25^{\mathrm{c}}$ & $2.16 \pm 0.01^{\mathrm{a}}$ & $0.39 \pm 0.00^{\mathrm{a}}$ & $4.54 \pm 0.00^{\mathrm{a}}$ & - & - \\
\hline CRT & $0.36 \pm 0.09^{\mathrm{g}}$ & - & - & - & - & - \\
\hline ORT & $0.88 \pm 0.01^{\mathrm{ef}}$ & - & - & - & - & - \\
\hline $\mathrm{CPT}$ & $0.98 \pm 0.00^{\mathrm{e}}$ & - & $0.06 \pm 0.00^{\mathrm{d}}$ & $0.12 \pm 0.02^{\mathrm{ef}}$ & - & - \\
\hline OPT & $0.38 \pm 0.00^{\mathrm{g}}$ & - & $0.01 \pm 0.00^{\mathrm{d}}$ & - & - & - \\
\hline CKDP & $0.59 \pm 0.00^{\mathrm{fg}}$ & - & $0.02 \pm 0.02^{\mathrm{d}}$ & - & - & - \\
\hline OKDP & $0.69 \pm 0.12^{\text {efg }}$ & - & - & - & - & - \\
\hline
\end{tabular}

Sample codes: see Table 1.

Table 3. DPPH radical scavenging activity and total phenol-flavonoid content of tested vegetable extracts. Different letters in each column show significant differences $(P<0.05) . \mathrm{IC}_{50}$ : The half maximal inhibitory concentration. GAE: Gallic acid equivalent, QE: Quercetin equivalent

\begin{tabular}{lccr}
\hline Vegetable extracts & $\begin{array}{c}\text { Antioxidant activity } \mathrm{IC}_{50} \\
\left(\mu \mathrm{gL}^{-1}\right)\end{array}$ & $\begin{array}{c}\text { Total phenolics } \\
(\mathrm{mg} \mathrm{GAE} / \mathrm{g} \text { extract })\end{array}$ & $\begin{array}{c}\text { Total flavonoids } \\
(\mathrm{mg} \text { QE/g extract })\end{array}$ \\
\hline CTE $_{\text {pulp }}$ & $2,565.59 \pm 27.58^{\mathrm{f}}$ & $32.74 \pm 0.46^{\mathrm{f}}$ & $19.89 \pm 0.93^{\mathrm{f}}$ \\
TE $_{\text {pulp }}$ & $1706.00 \pm 69.90^{\mathrm{e}}$ & $49.14 \pm 0.53^{\mathrm{e}}$ & $26.78 \pm 0.43^{\mathrm{e}}$ \\
CTE $_{\text {peel }}$ & $909.07 \pm 9.44^{\mathrm{c}}$ & $4.84 \pm 0.24^{1}$ & $64.13 \pm 0.88^{\mathrm{c}}$ \\
OTE $_{\text {peel }}$ & $813.83 \pm 4.65^{\mathrm{c}}$ & $9.39 \pm 0.10^{\mathrm{h}}$ & $72.87 \pm 0.97^{\mathrm{b}}$ \\
CPE $_{\text {pulp }}$ & $2,706.32 \pm 158.85^{\mathrm{f}}$ & $19.40 \pm 0.21^{\mathrm{g}}$ & $18.74 \pm 0.50^{\mathrm{f}}$ \\
OPE $_{\text {pulp }}$ & $1,331.72 \pm 14.92^{\mathrm{d}}$ & $31.22 \pm 3.26^{\mathrm{f}}$ & $41.13 \pm 0.73^{\mathrm{d}}$ \\
CPE $_{\text {peel }}$ & $1730.21 \pm 56.64^{\mathrm{e}}$ & $33.79 \pm 0.58^{\mathrm{f}}$ & $63.74 \pm 1.01^{\mathrm{c}}$ \\
OPE & $79.90 \pm 1.12^{\mathrm{d}}$ & $125.84 \pm 1.93^{\mathrm{a}}$ \\
CRT & $392.11 \pm 6.66^{\mathrm{b}}$ & $85.09 \pm 0.43^{\mathrm{bc}}$ & $3.51 \pm 0.27^{\mathrm{h}}$ \\
ORT & $>20.000$ & $134.13 \pm 2.76^{\mathrm{a}}$ & $5.58 \pm 0.20^{\mathrm{gh}}$ \\
CPT & $>20.000$ & $6.78 \pm 0.22^{\mathrm{h}}$ & $4.09 \pm 0.25^{\mathrm{h}}$ \\
OPT & $>20.000$ & $7.20 \pm 0.37^{\mathrm{h}}$ & $1.20 \pm 0.28^{1}$ \\
CKDP & $>20.000$ & $82.29 \pm 1.84^{\mathrm{cd}}$ & $4.35 \pm 0.24^{\mathrm{h}}$ \\
OKDP & $4,649.03 \pm 61.54^{\mathrm{g}}$ & $89.03 \pm 1.74^{\mathrm{b}}$ & $7.01 \pm 0.36^{\mathrm{g}}$ \\
Quercetin & $4,878.15 \pm 49.58^{\mathrm{h}}$ & & \\
\hline
\end{tabular}


Table 4. Antibacterial activities of tested vegetable extracts. Different letters in each column show significant differences $(P<0.05)$

\begin{tabular}{lc}
\hline Mean diameter of inhibitory zones & S. epidermidis \\
\hline Treatments & - \\
\hline CTE $_{\text {pulp }}$ & - \\
OTE $_{\text {pulp }}$ & - \\
CTE $_{\text {peel }}$ & - \\
OTE peel $_{\text {CPE }}$ pulp & - \\
OPE pulp & - \\
CPE & - \\
OPEel & $14.00 \pm 0.58^{\mathrm{d}}$ \\
CRT & - \\
ORT & - \\
CPT & - \\
OPT & - \\
CKDP & - \\
OKDP & - \\
Penicillin & $17.14 \pm 1.01^{\mathrm{c}}$ \\
Ampicillin & $31.57 \pm 0.20^{\mathrm{b}}$ \\
Sulfamethoxazole & $42.00 \pm 0.00^{\mathrm{a}}$ \\
Methanol & - \\
\hline
\end{tabular}

Sample codes: see Table 1 .

capacity of Pala-49 cultivar (4.41 folds and 2.03 folds for peel and pulp, respectively). Pulp of Topan-374 cultivar was characterised by significantly higher content of total phenolics content than pulp of Pala-49, and this content improved with organic cultivation (Table 3). Among the studied vegetables, two of the eggplant cultivars responded to organic farming more positively in our study. Consistent with our results, Raigon et al. (2010) reported strong adaptability of eggplant to organic cultivation due to its resistance or tolerance to a wide range of diseases and pests that affect other vegetable crops in the same family, such as tomato and pepper.

Many studies showed that the peel of the eggplants is rich in anthocyanins and pulp part is also rich in phenolic acids. Anthocyanins and phenolic acids in eggplant have been shown to have strong antioxidant ability in various studies (Niño-Medina et al., 2017). Anthocyanins are phenolic compounds of the flavonoid group. The peels of two eggplant cultivars had the highest total flavonoid contents, and only peels of both cultivars contained cyanidin, belonging to the group of anthocyanins, in our study. The highest antioxidant capacity was obtained for the organic peel of Pala-49, probably due to its highest content of individual phenolic substances and total phenol-flavonoid content. $\mathrm{IC}_{50}$ values of Pala-49 cultivar showed a negative correlation with total phenol and flavonoid contents $(r=-0.88$ and -0.90 , respectively, $P<0.05)$, and it can be said that the increase in total phenol and flavonoid contents due to organic cultivation caused an increase in antioxidant capacity. Furthermore, direct correlation was observed between antioxidant potential and total phenolic content of Topan-374 cultivar $(r=-0.94)$.

Lima et al. (2008) made a comparison between conventional and organic methods evaluating the differences in phenol and flavonoid contents in the peel of eggplant. No significant difference 
was found in total flavonoid contents for the two cultivation methods, and total phenolic content was higher with conventional method. On the contrary, organic cultivation elevated both total phenol and flavonoid contents of the peels in our study. Singh et al. (2017) reported that organic growing positively influenced the phenolic profile of eggplant skin extract but not antioxidant capacity. Luthria et al. (2010) did not observe significant difference in phenolic content of eggplant samples grown with organic and conventional farming practices with their studied two eggplant cultivars. On the other hand, both phenolic profile and antioxidant capacity in both eggplant cultivars were improved with organic cultivation method in our study.

Strong antibacterial activity was obtained only with organic peels of Pala-49 eggplant cultivar against $S$. epidermidis, and it should be related to the highest antioxidant capacity and phenolic constituents, flavonoids, especially anthocyanins, of the peels (Table 3). Antibacterial potential of the peel against S. epidermidis is presented for the first time. Akhbari et al. (2019) investigated the antibacterial potential of the anthocyanin-rich extract of eggplant peels, and a high antibacterial potential was observed against K. pneumonia, $P$. vulgaris, E. coli, and P. aeruginosa, but susceptibility of $S$. epidermidis and $S$. aureus were not found to the extract.

Chlorogenic acid amounts were higher (2.44 times) in organically grown Rio Grande tomato cultivar. Organic farming was less efficient in Pink tomato cultivar considering chlorogenic acid, $t$-ferulic acid, and caffeic acid quantities (Table 2). Organic Rio Grande tomatoes had significantly higher total phenol and flavonoid contents than the conventional ones, but no significant difference was obtained in total phenolic content between organic and conventional Pink tomato, and organic Pink tomato had lower total flavonoid content than conventional one. Difference in the antioxidant capacity was not found for any tomato cultivars or cultivation system (Table 3). Anton et al. (2014) evaluated the effect of cultivation system on the content of individual polyphenols, total phenolics, and antioxidant capacity of four tomato cultivars. In consistence with our results, none of their cultivars showed higher radical scavenging results either in organic or conventional system. They also reported that the cultivation system had minor effect on polyphenols content and no impact on antioxidant capacity and total phenolic. Vallverdú-Queralt et al. (2012) analysed tomatoes from conventional and organic production systems and revealed higher levels of phenolic compounds in organic tomatoes. Borguini et al. (2013) compared the effect of organic and conventional cultivation on the antioxidant compound content and antioxidant activity of the Carmen tomato cultivar. Organically grown tomatoes presented higher content of total phenolics and higher antioxidant activity than the conventional ones. Hallmann (2012) showed that organic growing system positively affected the nutritional value, total phenolic acid and total flavonoid contents in two tomato types (standard and cherry). A similar impact of the cultivation method on total phenol and flavonoid contents in organic and conventional Rio Grande tomato was also noticed, but total phenolic content was not dependent on the cultivation system in Pink tomato in our study. Similar result was observed by Ilic et al. (2014), who indicated that the effect of cultivar differences in tomato was more enhanced than differences due to cultivation method on fruit quality.

Organic bell peppers had a significantly higher (1.17 folds) content of chlorogenic acid compared to conventional ones (Table 2). Organically grown bell peppers showed less antioxidant potential but higher total phenol and flavonoid contents than conventionally grown ones (Table 3). In consistence with the result of our total phenol and flavonoid contents, de Oliveira Pereira et al. (2016) found more total phenolic compounds in organic bell pepper. On the other hand, antioxidant capacity of their organic bell pepper was higher than conventional ones. Bicikliski et al. (2018) 
also determined that organic production of bell peppers resulted higher antioxidant content compared to conventional ones. Hallmann and Rembiałkowska (2012) showed that organic bell pepper fruits contained significantly more chlorogenic acid, gallic acid, quercetin, kaempferol, and total phenolic acids compared to conventional ones. Similarly, higher chlorogenic acid and total phenol-flavonoid contents were observed with organic bell peppers in our study. Szafirowska and Elkner (2008) showed that pepper fruits obtained from organic cultivation system comprised higher amounts of total flavonoids and polyphenols than conventional ones, like our study.

Differences in the impact of organic cultivation on phenolic constituents and antioxidant potential in different studies may be attributed to the climate, weather, and soil structure of the environment, where the product is grown. It is well known that the cultivar and mode of fertilisation have significant effects on the biosynthesis of phenolic compounds in plants. Generally, many studies showed that organic agriculture system could result in food with higher polyphenol quantity (Vallverdú-Queralt et al., 2012). In the absence of synthetic pesticides, the plant may be exposed to more stressful conditions, resulting in an increase in defence related substances, such as phenolic compounds (Brandt and Mølgaard, 2001; Faller and Fialho, 2010). Furthermore, plants are expected to weaken their natural defence mechanisms, when they are grown with artificial nutrients and pesticides in conventional cultivation system. This is thought to contribute to a reduction in disease resistance and defence-related secondary metabolite content, like phenolic substances. Some investigations indicated that slower nitrogen release, as happens when manure is used instead of synthetic fertilisers, results in higher polyphenol content in food, so organic foods have more health-promoting substances than conventional ones (Fawzy et al., 2016).

\section{CONCLUSIONS}

Impact of organic cultivation system on some vegetables of the Solanaceae family indicated that it varies depending on the plant species and the cultivar you work with. The predominant phenolic compound found in all cultivars was chlorogenic acid. Both organic eggplant cultivars produced fruits that have higher antioxidant capacity and phenolic constituents. Especially, consumption of organic eggplants with their peels is healthier because of the exploitation of more phenolic compounds. Organic cultivation of Pala-49 eggplant cultivar provided more enhancements in antioxidant potency and phenolic constituents. Organic Rio Grande tomato and bell pepper also showed enhanced phenolic compound contents. On the contrary, Pink tomato cultivar was more appropriate for conventional cultivation, accumulating more total flavonoid content under this cultivation condition. The health-promoting effect of organic farming on Pala-49 and Topan-374 eggplant cultivars, Rio Grande tomato, and Kandil Dolma bell pepper was proved with this study. Organic cultivation provided an advantage to obtain fruit vegetables with higher amounts of phenolic compounds, which brings additional value to these crops in terms of antioxidant potency as well as a lower environmental impact.

\section{ACKNOWLEDGEMENT}

This study was supported by Bolu Abant Izzet Baysal University Research Foundation (BAP 18.03.01.1275). 


\section{REFERENCES}

Akhbari, M., Hamedi, S., and Aghamiri, Z.S. (2019). Optimization of total phenol and anthocyanin extraction from the peels of eggplant (Solanum melongena L.) and biological activity of the extracts. Journal of Food Measurement and Characterization, 13(4): 3183-3197.

Anton, D., Matt, D., Pedastsaar, P., Bender, I., Kazimierczak, R., Roasto, M., Kaart, T., Luik, A., and Püssa, T. (2014). Three-year comparative study of polyphenol contents and antioxidant capacities in fruits of tomato (Lycopersicon esculentum Mill.) cultivars grown under organic and conventional conditions. Journal of Agricultural and Food Chemistry, 62(22): 5173-5180.

Bicikliski, O., Trajkova, F., Mihajlov, L., Jordanovska, S., and Tashev, K. (2018). Vitamin C and total antioxidant content in pepper fruits (Capsicum annuum L.): Comparative analysis of peppers grown in conventional and organic agricultural systems. Annual Research and Review in Biology, 27(5): 1-11.

Blois, M.S. (1958). Antioxidant determinations by the use of a stable free radical. Nature, 181: 1199-1200.

Borguini, R.G., Bastos, D.H.M., Moita-Neto, J.M., Capasso, F.S., and Torres, E.A.F.D.S. (2013). Antioxidant potential of tomatoes cultivated in organic and conventional systems. Brazilian Archives of Biology and Technology, 56(4): 521-529.

Brandt, K. and Mølgaard, J.P. (2001). Organic agriculture: does it enhance or reduce the nutritional value of plant foods? Journal of the Science of Food and Agriculture, 81(9): 924-931.

Caleja, C., Ribeiro, A., Filomena Barreiro, M., and C.F.R. Ferreira, I. (2017). Phenolic compounds as nutraceuticals or functional food ingredients. Current Pharmaceutical Design, 23(19): 2787-2806.

de Oliveira Pereira, F., dos Santos Pereira, R., de Souza Rosa, L., and Teodoro, A.J. (2016). Organic and conventional vegetables: Comparison of the physical and chemical characteristics and antioxidant activity. African Journal of Biotechnology, 15(33): 1746-1754.

Faller, A.L.K. and Fialho, E.F.N.U. (2010). Polyphenol content and antioxidant capacity in organic and conventional plant foods. Journal of Food Composition and Analysis, 23(6): 561-568.

Fawzy, Z.F., Shedeed, S.I., and Hassan, N.M. (2016). A review of organic agricultural of some vegetables crops. American Journal of Food Science and Health, 2(3): 25-31.

Hallmann, E. (2012). The influence of organic and conventional cultivation systems on the nutritional value and content of bioactive compounds in selected tomato types. Journal of the Science of Food and Agriculture, 92(14): 2840-2848.

Hallmann, E. and Rembiałkowska, E. (2012). Characterisation of antioxidant compounds in sweet bell pepper (Capsicum annuum L.) under organic and conventional growing systems. Journal of the Science of Food and Agriculture, 92(12): 2409-2415.

Ilic, Z.S., Kapoulas, N, and Sunic, L. (2014). Tomato fruit quality from organic and conventional production. In: Pilipavicius, V. (Ed.), Organic Agriculture towards Sustainability. In Tech Europe, Rijeka, Croatia, pp. 147-169.

Lima, G.P.P., Da Rocha, S.A., Takaki, M., Ramos, P.R.R., and Ono, E.O. (2008). Comparison of polyamine, phenol and flavonoid contents in plants grown under conventional and organic methods. International Journal of Food Science and Technology, 43(10): 1838-1843.

Luthria, D., Singh, A.P., Wilson, T., Vorsa, N., Banuelos, G.S., and Vinyard, B.T. (2010). Influence of conventional and organic agricultural practices on the phenolic content in eggplant pulp: plant-to-plant variation. Food Chemistry, 121(2): 406-411.

Niño-Medina, G., Urías-Orona, V., Muy-Rangel, M.D., and Heredia, J.B. (2017). Structure and content of phenolics in eggplant (Solanum melongena) - a review. South African Journal of Botany, 111: 161-169. 
Official Gazette (2010). Regulation on principles and application of organic agriculture No: 27676 (in Turkish).

Raigon, M.D., Rodriguez-Burruezo, A., and Prohens, J. (2010). Effects of organic and conventional cultivation methods on composition of eggplant fruits. Journal of Agricultural and Food Chemistry, 58(11): 6833-6840.

Simonne, A.H., do Nascimento Nunes, C., and Brecht, J.K. (2011). Tomato and other solanaceous fruits. In: Terry, L.A. (Ed.), Health-promoting properties of fruit and vegetables. CAB International, Oxfordshire, UK, pp. 321-350.

Singh, A.P., Wang, Y., Olson, R.M., Luthria, D., Banuelos, G.S., Pasakdee, S., Vorsa, N., and Wilson, T. (2017). LC-MS-MS analysis and the antioxidant activity of flavonoids from eggplant skins grown in organic and conventional environments. Food and Nutrition Sciences, 8(9): 873-888.

Szafirowska, A. and Elkner, K. (2008). Yielding and fruit quality of three sweet pepper cultivars from organic and conventional cultivation. Vegetable Crops Research Bulletin, 69(1): 135-143.

Turker, A.U., Yildirim, A.B., Tas, I., Ozkan, E., and Turker, H. (2021). Evaluation of some traditional medicinal plants: phyto-chemical profile, antibacterial and antioxidant potentials. Romanian Biotechnological Letters, 26(2): 2499-2510.

Vallverdú-Queralt, A., Jáuregui, O., Medina-Remón, A., and Lamuela-Raventós, R.M. (2012). Evaluation of a method to characterize the phenolic profile of organic and conventional tomatoes. Journal of Agricultural and Food Chemistry, 60(13): 3373-3380.

Yamaguchi, M. (1983). Solanaceous fruits: tomato, eggplant, peppers, and others. In: World vegetables. Springer, Dordrecht, pp. 291-311.

Yüzbaşığlu, R. (2018). Bireylerin organik sebze-meyve tüketimini etkileyen faktörlerin belirlenmesi (Tokat ili merkezi örneği). (Determination of factors affecting the organic fruit and vegetable consumption of individuals (Tokat city center sample)). Türk Tarım ve Doğa Bilimleri Dergisi 5(4): 433-439.

Open Access. This is an open-access article distributed under the terms of the Creative Commons Attribution-NonCommercial 4.0 International License (https://creativecommons.org/licenses/by-nc/4.0/), which permits unrestricted use, distribution, and reproduction in any medium for non-commercial purposes, provided the original author and source are credited, a link to the CC License is provided, and changes - if any - are indicated. 